\title{
A large-scale study on the effect of age at first calving, dam parity, and birth and calving month on first-lactation milk yield in Holstein Friesian dairy cattle
}

\author{
M. Van Eetvelde, ${ }^{1 *}$ G. de Jong, ${ }^{2}$ K. Verdru, ${ }^{1}$ M. L. van Pelt, ${ }^{2}$ M. Meesters, ${ }^{1}$ and G. Opsomer ${ }^{1}$ \\ ${ }^{1}$ Department of Reproduction, Obstetrics and Herd Health, Faculty of Veterinary Medicine, Ghent University, Salisburylaan 133, 9820 Merelbeke, \\ Belgium \\ ${ }^{2}$ Cooperative CRV UA, Animal Evaluation Unit, PO Box 454, 6800 AL Arnhem, the Netherlands
}

\section{ABSTRACT}

Milk yield during first lactation is an important economical trait. Age at first calving (AFC) is considered an important predictor of subsequent milk yield. In addition, both season of birth, as well as season of calving, have been shown to influence milk production, with conflicting results. Finally, higher parity of the dam has been associated with a lower performance of the offspring. The aim of the present study was to assess the effect of the above-mentioned factors based on a large-scale study and to rank the most important determinants for first-lactation milk yield. Data on 3,810,678 Holstein Friesian heifers, born in Belgium and the Netherlands between 2000 and 2015, were provided by Cooperative CRV and CRV BV (Arnhem, the Netherlands) and consisted of birth dates, calving dates, and first-lactation productions. In addition, herd, sire, and dam information was provided. Linear regression models were built with herd-calving year and sire as random effects and 305-d energy-corrected milk (ECM) yield during first lactation as outcome variable. Birth month, calving month, parity of the dam, and AFC were included as fixed effects in the model and a dominance analysis was performed to rank the associated factors according to importance. Results revealed $\mathrm{AFC}$ to be the most important factor $\left(\mathrm{R}^{2}=0.047\right)$, with an increase in ECM up to an age of 33 mo. Calving month was a more important predictor than birth month $\left(\mathrm{R}^{2}=0.010\right.$ vs. $\mathrm{R}^{2}=0.002$, respectively), with the highest first-lactation production in heifers calving in October to December, and the lowest in heifers calving in June and July. Birth month had a limited effect on first-lactation milk yield $\left(\mathrm{R}^{2}=0.002\right)$, potentially masked by rearing strategies during early life. Finally, parity of the dam $\geq 3$ was associated with a reduced

Received February 26, 2020.

Accepted August 8, 2020.

*Corresponding author: mieke.vaneetvelde@ugent.be
ECM of the offspring $\left(\mathrm{R}^{2}=0.002\right)$. In conclusion, our results show AFC to be an important determinant of milk yield during first lactation. In addition, seasonal patterns in milk production are seen, which should be further explored to identify the underlying mechanism. Key words: first lactation, age at first calving, birth month, calving month, parity of the dam

\section{INTRODUCTION}

In dairy cattle, milk yield during first lactation is considered to be an important economical trait, as it has been shown to be a predictor of lifetime performance and longevity (Jairath et al., 1995, Haworth et al., 2008). As a consequence, researchers have repeatedly studied and identified factors associated with the amount of milk produced during first lactation. In our previous study, assessing the effect of several pre- and postnatal factors on first-lactation performance, age at first calving (AFC) was shown to be strongly associated with first-lactation milk yield (Van Eetvelde et al., 2017). As decreasing the AFC reduces rearing costs, the aim is to have heifers calving for the first time no later than 24 mo (Ettema and Santos, 2004). A further decrease in AFC to less than 22 to 23 mo is generally accepted to have a negative effect on yields of milk, fat, and protein (Nilforooshan and Edriss, 2004; Froidmont et al., 2013; Eastham et al., 2018). However, the effect of an older AFC on first-lactation performance is less clear. Although some authors found older heifers to have a lower first-lactation milk yield (Haworth et al., 2008; Froidmont et al., 2013), other authors report an increase in milk yield with increasing age (Van Eetvelde et al., 2017; Eastham et al., 2018). In addition to AFC, our earlier study revealed an effect of birth season on performance during first lactation, whereas no effect of calving season was found (Van Eetvelde et al., 2017). This might be explained by the fact that a rather low number of animals and herds was included in this study, resulting in a limited variation in calving season. Although the effect of birth season on first-lactation milk 
yield has been previously described, studies on seasonal patterns are not unambiguous; although summer-born calves have been shown to produce more milk during first lactation (Soberon et al., 2012; Chester-Jones et al., 2017), the odds of finishing first lactation have been shown to be higher in winter-born calves (Bach, 2011). Furthermore, Soberon et al. (2012) reported the effect of birth season on milk yield differs between herds, indicating other factors to be more important. Studies on first-lactation performance in relation to calving season report conflicting results; although some authors found milk yield to be the lowest following calving in summer (Maciuc, 2009; Mohd Nor et al., 2013), others reported the highest milk yields to be produced by summer-calvers (Froidmont et al., 2013). Although in these previous studies seasonal effects on milk yield were described, none of them included both season of birth and season of calving. Combining birth season and calving season into one model would enable us to further assess when the main environmental influences on later performance occur: during early or later life.

Finally, parity of the dam has been repeatedly identified as a prenatal influencer of first-lactation performance, indicating a benefit for heifers conceived by younger dams (Fuerst-Waltl et al., 2004; González-Recio et al., 2012). However, this could not be confirmed in our earlier study, possibly due to the limited number of animals and the lack of variation in dam parity (Van Eetvelde et al., 2017).

The aim of the present study was to assess the effect of the above-mentioned factors on first-lactation milk yield based on a large data set of dairy heifers. In most of the previously mentioned studies, the effect of only one factor was demonstrated. By studying all these risk factors at the same time and accounting for herd effects in the model, we wanted to explore the possible interactions between these factors. In addition, we aimed to rank these factors according to their importance for the milk yield during first lactation.

\section{MATERIALS AND METHODS}

\section{Data Collection}

The initial data set for this study was provided by CRV (Arnhem, the Netherlands) and contained milk production data of 4,055,678 dairy heifers. Heifers had at least $75 \%$ proportion of Holstein Friesian genes and were born in Flemish (Belgian) and Dutch herds between January 2000 and May 2015. All animals were registered for milk recording following first calving between September 2001 and February 2017. Herd, birth date, calving date, duration of lactation, milk yield, and milk composition during first lactation of the heif- ers were available. In addition, sire, dam, and parity of the dam were provided.

\section{Data Selection and Calculations}

All data provided by CRV were loaded into the statistical program $\mathrm{R}$ version 3.6.1 (R Core Team, 2019) and merged into one file. Animals with incomplete sire and dam information were rejected $(\mathrm{n}=112,233)$. In addition, selection was made based on AFC and length of lactation. Animals with a first calving before the age of $21 \mathrm{mo}(\mathrm{n}=10,855)$ or after the age of $35 \mathrm{mo}(\mathrm{n}=$ $31,055)$ were removed from further analyses. Milk yield data of lactations with a duration of less than $250 \mathrm{~d}$ ( $\mathrm{n}=75,349)$ were considered not reliable enough and therefore excluded. In addition, lactations of more than $730 \mathrm{~d}(\mathrm{n}=15,508)$ were removed, as in these cases, the next (second) calving date of the heifer might not have been registered. After this screening, 3,810,678 heifers remained for further analyses.

For each heifer, the 305-d ECM yield with $4 \%$ fat and $3.3 \%$ protein was estimated based on 305-d milk, fat, and protein yields (IFCN, 2012) and was calculated as follows:

$$
\begin{gathered}
\mathrm{ECM}=[0.3246 \times 305-\mathrm{d} \text { milk production }(\mathrm{kg})] \\
+[12.86 \times 305-\mathrm{d} \text { fat production }(\mathrm{kg})] \\
+[7.04 \times 305-\mathrm{d} \text { protein production }(\mathrm{kg})] .
\end{gathered}
$$

\section{Statistical Analyses}

All statistical analyses were performed in R 3.6.1 ( $\mathrm{R}$ Core Team, 2019). To investigate which factors had a significant effect on the 305-d ECM during first lactation, linear mixed models were built using the package lme4 (Bates et al., 2015). The interaction among herd $(\mathrm{n}=26,189)$ and year of calving $(\mathrm{n}=17)$ was defined as herd-calving year and included as random effect in the model, to account for between-herd differences and within-herd progress over time. In addition, sire was included as random effect to account for differences in genetic background. The other predictor variables (birth month, calving month, AFC, and parity of the dam) and their significant interactions were included as fixed effects.

Finally, following linear regression model was used:

$$
\begin{gathered}
\mathrm{Y}_{\mathrm{ijklmno}}=\mu+\mathrm{BM}_{\mathrm{i}}+\mathrm{CM}_{\mathrm{j}}+\mathrm{AFC}_{\mathrm{k}}+\mathrm{DPAR}_{\mathrm{l}}+\mathrm{BM}_{\mathrm{i}} \\
\times \mathrm{CM}_{\mathrm{j}}+\mathrm{BM}_{\mathrm{i}} \times \mathrm{AFC}_{\mathrm{k}}+\mathrm{SI}_{\mathrm{m}}+\mathrm{HCY}_{\mathrm{n}}+\mathrm{e}_{\mathrm{ijk} \mathrm{kmno},}
\end{gathered}
$$

where $Y_{\mathrm{ijklmno}}$ is the 305-d ECM of a heifer; $\mu$ is the overall mean; $\mathrm{BM}_{\mathrm{i}}$ is fixed effect of birth month $\mathrm{i} ; \mathrm{CM}_{\mathrm{j}}$ 


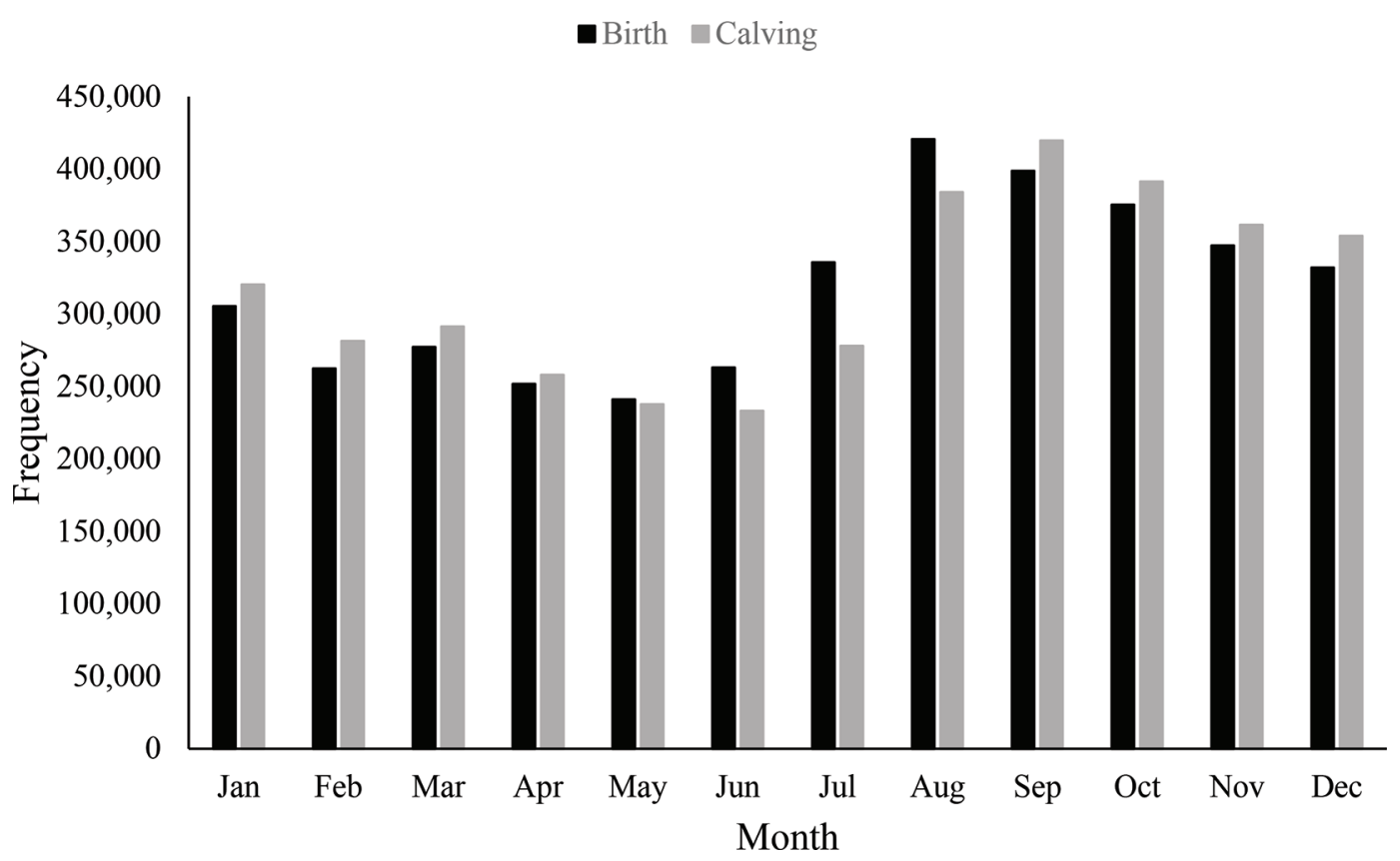

Figure 1. Distribution of births and calvings by month.

is fixed effect of calving month $\mathrm{j}$; $\mathrm{AFC}_{\mathrm{k}}$ is fixed effect of age at first calving $\mathrm{k}$; $\mathrm{DPAR}_{1}$ is fixed effect of dam parity $\mathrm{l} ; \mathrm{BM}_{\mathrm{i}} \times \mathrm{CM}_{\mathrm{j}}$ is fixed effect of the interaction between birth month $\mathrm{i}$ and calving month $\mathrm{j} ; \mathrm{BM}_{\mathrm{i}} \times \mathrm{AFC}_{\mathrm{k}}$ is fixed effect of the interaction between birth month $\mathrm{i}$ and $\mathrm{AFC}_{\mathrm{k}} ; \mathrm{SI}_{\mathrm{m}}$ is random effect of sire $\mathrm{m} ; \mathrm{HCY}_{\mathrm{n}}$ is random effect of herd-calving year $\mathrm{n}$; and $\mathrm{e}_{\mathrm{ijklmno}}$ is random residual effect. The results of the model are presented as least squares means \pm standard error $(\mathrm{LSM} \pm \mathrm{SE})$, and multiple comparisons were performed using a Tukey test (significance at $P<0.05$ ).

Statistical significance $(P<0.001)$ was easily reached due to the size of the data set and $P$-values could not be used to determine the most important factor in the model. Moreover, multicollinearity was foreseeable, as month of calving is naturally a result of birth month and AFC. Hence, a dominance analysis was performed to evaluate the importance of each predictor in the regression model (Azen and Budescu, 2003). This method offers a general approach to compare predictors by including several other comparison methods (e.g., correlations and regression coefficients). Practically, this is realized by examining the unique variance accounted for by the predictor across all possible regression submodels involving that predictor. Outcomes of the dominance analysis are $R^{2}$ values for each predictor, which are adjusted for shared variances with other predictors (i.e., representing the real explained variance). In addition, the $\mathrm{R}^{2}$ of the individual effects in the model sum to the $\mathrm{R}^{2}$ of the full model, containing all pre- dictors (Azen and Traxel, 2009). In the present study, dominance analysis was performed using the $\mathrm{R}$ package dominanceanalysis (Bustos and Soares, 2019).

\section{RESULTS}

\section{Descriptive Analysis}

The 3,810,678 heifers included in the study were born over a period of 16 years (from 2000 to 2015), with an average of 238,167 heifers born per year. A limited number of these heifers calved during 2001 ( $\mathrm{n}=2,354)$ and during $2017(\mathrm{n}=1,401)$. Between 2002 and 2016, on average 253,795 first calvings were recorded each year. Month-of-birth and month-of-calving patterns are presented in Figure 1. Most calvings took place from August to December, with $49.2 \%$ of the heifers being born and $50.1 \%$ of the heifers calving during these 5 final months of the year.

Of the 26,189 farms in the data set, 3,287 farms contributed fewer than 10 heifers, and 13,861 farms contributed more than 100 heifers. The average number of heifers per farm was 146 .

The majority $(53.5 \%)$ of heifers were born out of firstand second-parity dams (Figure 2). On the other hand, only $3.9 \%$ of heifers were born of dams with a parity of 7 or higher. For this reason, dam parities of 7 and more were considered one group in further analyses.

The heifers included in the present study produced $7,574 \pm 1,320 \mathrm{~kg}$ of milk over a 305-d lactation, with 


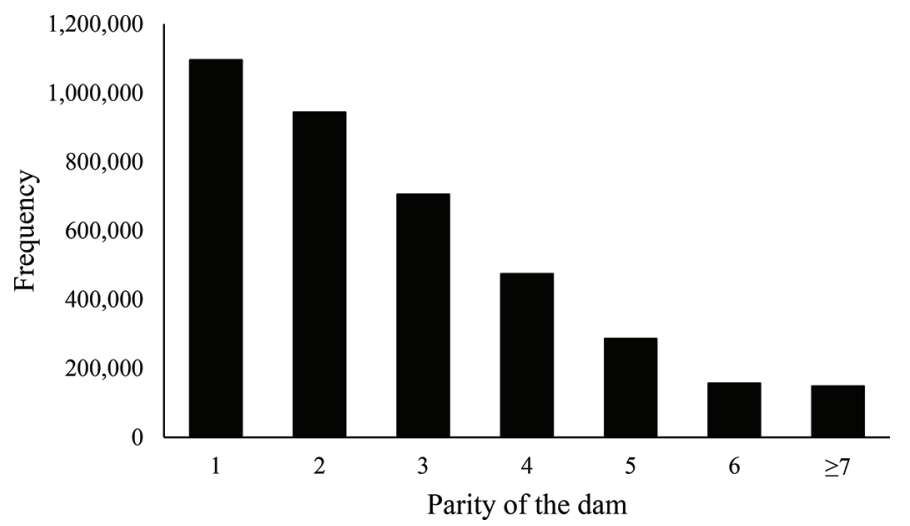

Figure 2. Distribution of births by parity of the dam.

$323 \pm 52 \mathrm{~kg}$ of fat and $262 \pm 44 \mathrm{~kg}$ of protein, resulting in an average 305 -d ECM of 8,453 $\pm 1,327 \mathrm{~kg}$. Distribution of the AFC is shown in Figure 3. The overall mean AFC was $785 \pm 72 \mathrm{~d}$, with $58.4 \%$ of heifers between 24 and 27 mo at first calving. From 2007 to 2016, a gradual decrease in average AFC was seen from $788 \pm$ $73 \mathrm{~d}$ to $770 \pm 68 \mathrm{~d}$. A large variation was seen between herds; for heifers calving in $2016(\mathrm{n}=245,664)$, the mean AFC on herd level ranged from $645 \pm 14$ to 1,040 $\pm 11 \mathrm{~d}$. Herd-level AFC was dependent on size of the herd; herds with fewer than 25 heifer calvings in 2016 had a mean AFC of $784 \pm 55 \mathrm{~d}$, compared with 762 \pm 53 and $753 \pm 52 \mathrm{~d}$ for herds with 25 to 50 and $>50$ heifers, respectively $(P<0.001)$. Overall, in all calving years a similar trend was seen, with lower AFC in larger herds $(P<0.001)$.

\section{Linear Regression Model}

Results of the regression model and dominance analysis are shown in Table 1. Regression models revealed no third-order interactions to be significant $(P<0.05)$, so further analysis was restricted to second-order interac-

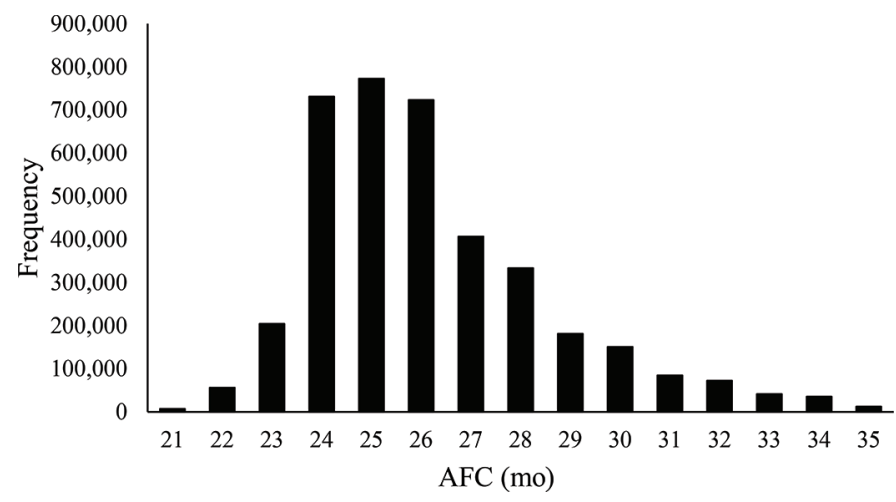

Figure 3. Distribution of age at first calving (AFC) in months.
Table 1. Results of the linear regression model for 305-d ECM yield, $P$-value, and dominance analysis $\left(\mathrm{R}^{2}\right)^{1}$

\begin{tabular}{lcc}
\hline Fixed effects & $P$-value & $\mathrm{R}^{2}$ \\
\hline Birth month & $<0.001$ & 0.002 \\
Calving month & $<0.001$ & 0.010 \\
AFC & $<0.001$ & 0.047 \\
Parity of the dam & $<0.001$ & 0.002 \\
Birth month $\times$ calving month & $<0.001$ & \\
Birth month $\times$ AFC & $<0.001$ & \\
\hline
\end{tabular}

${ }^{1}$ Results of a mixed regression model for the dependent variable (305-d ECM) with sire and herd-calving year as random effects and the following fixed effects: age at first calving (AFC), birth month, calving month and parity of the dam.

tions. The 2-way interactions between birth month and calving month and between birth month and AFC were significant $(P<0.001)$ and included in the final multivariable regression model. Birth month, calving month, AFC, and parity of the dam significantly influenced the 305-d ECM of the heifers $(P<0.001)$. The results of the dominance analysis showed an overall $\mathrm{R}^{2}$ for the fixed effects of 0.061 , suggesting that only a small proportion of variance in milk yield can be explained by the variables included in the model. Of the variables included, AFC is the most important determinant of first-lactation 305-d ECM, explaining more variance than all other predictors $\left(\mathrm{R}^{2}=0.047\right)$, followed by month of calving $\left(R^{2}=0.010\right)$. Birth month and parity of the dam explained the least of the variance $\left(\mathrm{R}^{2}=\right.$ 0.002 ).

A positive association was seen between AFC and milk yield during first lactation (Figure 4), with the lowest 305 -d ECM $(7,438 \pm 16.3 \mathrm{~kg})$ recorded for the 21 -mo AFC class, which was significantly $(P<0.001)$ lower than any other class. The highest 305-d ECM was recorded for heifers in the 34-mo AFC class $(8,598$ $\pm 9.3 \mathrm{~kg}$ ), but this was not significantly different compared with heifers of 33 and 35 mo $(8,565 \pm 9.5$ and $8,597 \pm 12.9 \mathrm{~kg}$, respectively).

A higher parity of the dam negatively influenced the daughter's milk yield (Figure 5). Heifers born out of first- and second-parity dams had a similar 305-d $\operatorname{ECM}(8,306 \pm 4.0$ and $8,307 \pm 4.1 \mathrm{~kg}$, respectively, $P$ $=0.97$ ), significantly higher than heifers born out of higher-parity dams. Daughters of the $\geq 7$ parity class dams had a $290 \pm 3.3 \mathrm{~kg}$ lower 305-d ECM compared with daughters of first-parity dams $(P<0.001)$.

Milk yield during first lactation was influenced by the interaction between birth month and calving month. However, variation explained by calving month was 5 times higher compared with variation by birth month $\left(\mathrm{R}^{2}=0.010\right.$ and $\mathrm{R}^{2}=0.002$, respectively). Figure 6 shows the birth month-calving month interaction and the effect on 305-d ECM of the heifers. Overall, heif- 


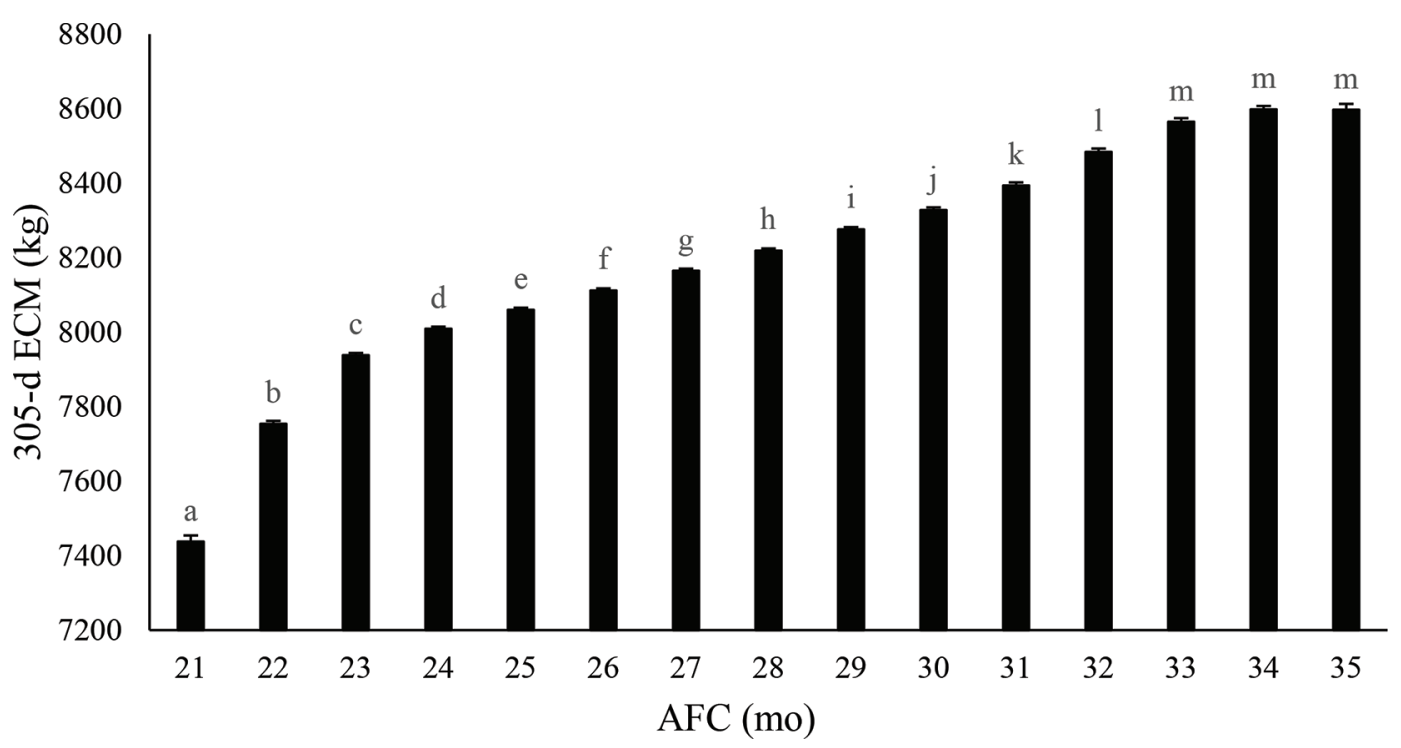

Figure 4. Results of the multivariable regression model including birth month, calving month, age at first calving (AFC) and parity of the dam; effect of AFC on 305-d ECM (LSM \pm SE). Different superscripts indicate significant differences $(P<0.05)$.

ers calving during autumn produced more milk. The highest mean 305-d ECM was recorded for heifers calving in November $(8,319 \pm 6.9 \mathrm{~kg})$, but this was not significantly higher than for heifers calving in October or December. Among the November-calvers, the production was influenced by their month of birth, but this variation was quite limited $(8,242 \pm 28.3 \mathrm{~kg}$ for heifers born in April, and 8,369 $\pm 18.0 \mathrm{~kg}$ for heifers born in July). Heifers calving in June and July had the lowest mean 305-d ECM during first lactation (8,098 \pm 7.1 and $8,096 \pm 7.3 \mathrm{~kg}$, respectively), which was less than heifers calving in any other month. Among

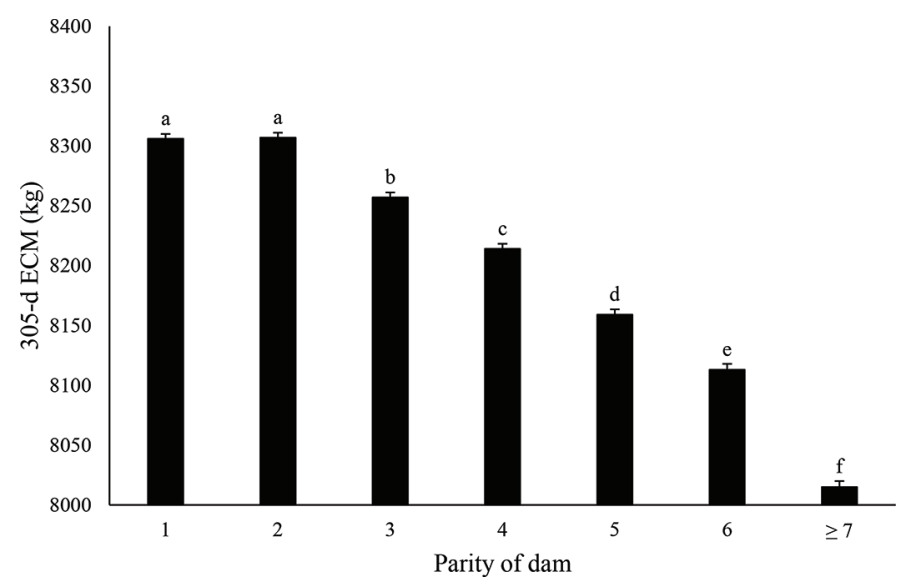

Figure 5. Results of the multivariable regression model including birth month, calving month, age at first calving and parity of the dam; effect of parity of the dam on 305-d ECM $(\mathrm{LSM} \pm \mathrm{SE})$. Different superscripts indicate significant differences $(P<0.05)$. the June-calvers, the variation in 305-d ECM by birth month was larger, from 8,041 $\pm 17.1 \mathrm{~kg}$ in May-born to $8,221 \pm 21.4 \mathrm{~kg}$ in January-born heifers. The overall effect of birth month on 305-d ECM was small $\left(\mathrm{R}^{2}=\right.$ $0.002)$. The highest mean milk yield was seen in heifers born in December $(8,243 \pm 6.6 \mathrm{~kg})$, but this was not significantly different from heifers born in October, November, and January. On the other hand, April-born heifers had the lowest 305-d ECM production, similar to heifers born between March and August $(P>0.05)$.

\section{DISCUSSION}

\section{Age at First Calving}

The average AFC of $785 \pm 72 \mathrm{~d}$ (or $26.2 \pm 2.4 \mathrm{mo}$ ) observed in the present study is in accordance with previous studies conducted in the Netherlands and Belgium (Froidmont et al., 2013; CRV, 2018a, b). Between 2007 and 2016, the AFC decreased by $18 \mathrm{~d}$. This trend of decreasing AFC in dairy cattle has been previously described and is suggested to represent earlier maturity in heifers, accomplished by better calf-rearing practices or intense selection for high milk yield (González-Recio et al., 2004; Hare et al., 2006). On average, a lower AFC was recorded in larger herds, which has been previously reported by USDA (2002). Indeed, larger herd size has been shown to be associated with better reproductive performance, such as higher insemination and pregnancy rates, lower AFC, and shorter calving intervals (Jago and Berry, 2011; Denis-Robichaud et al., 2016). This might be explained by the fact that larger farms 
more often use protocols or management practices such as timed AI or automated activity monitoring for reproduction management compared with smaller family farms (Jago and Berry, 2011; Froidmont et al., 2013). In addition, the large variation in AFC between herds suggests that this trait is strongly influenced by the herd-management and strategic choices of the farmer. However, as detailed management data were not available for the farms included in this study, it was not possible to identify the individual management factors associated with the herd-level AFC.

The multivariable regression model had a total $\mathrm{R}^{2}$ of 0.061 , indicating that only a small amount of variation in first-lactation milk yield can be explained by the factors included in our model. However, the regression model revealed AFC to be the most important predictor for 305-d ECM, with an absolute dominance over all other tested variables. The lowest 305-d ECM was recorded in the youngest heifers, which has already been repeatedly described (Curran et al., 2013; Van Eetvelde et al., 2017; Eastham et al., 2018). Furthermore, in the present study a plateau in milk yield was reached at an $\mathrm{AFC}$ of $33 \mathrm{mo}$, with no further increase in milk yield in older heifers. A possible explanation might be that the number of animals in each age class decreased with older age. These results are in accordance with our previous study (Van Eetvelde et al., 2017) and the recent study of Eastham et al. (2018), who described a positive association between AFC and 305-d milk yield with a plateau at 34 to $42 \mathrm{mo}$. In contrast, several other studies reported an optimum in milk yield at an AFC of 22 to 26 mo, with similar or even lower milk yields in older heifers (Curran et al., 2013; Froidmont et al., 2013). This might be at least partly explained by the fact that most studies used pure milk yield (without correction for milk solids) instead of ECM. Milk solids, especially fat percentage, have been shown to increase with older AFC, even when no further increase in milk yield is seen (Curran et al., 2013; Eastham et al., 2018). Indeed, in the present study, milk fat percentage (in a lactation of $305 \mathrm{~d}$ ) was the highest in the heifers with the oldest AFC. This higher production of milk fat by older heifers is suggested to be related to their ability to ingest larger amounts of roughages (Pirlo et al., 2000). Hence, the fact that older heifers produced more milk solids in combination with an equal (or higher) milk

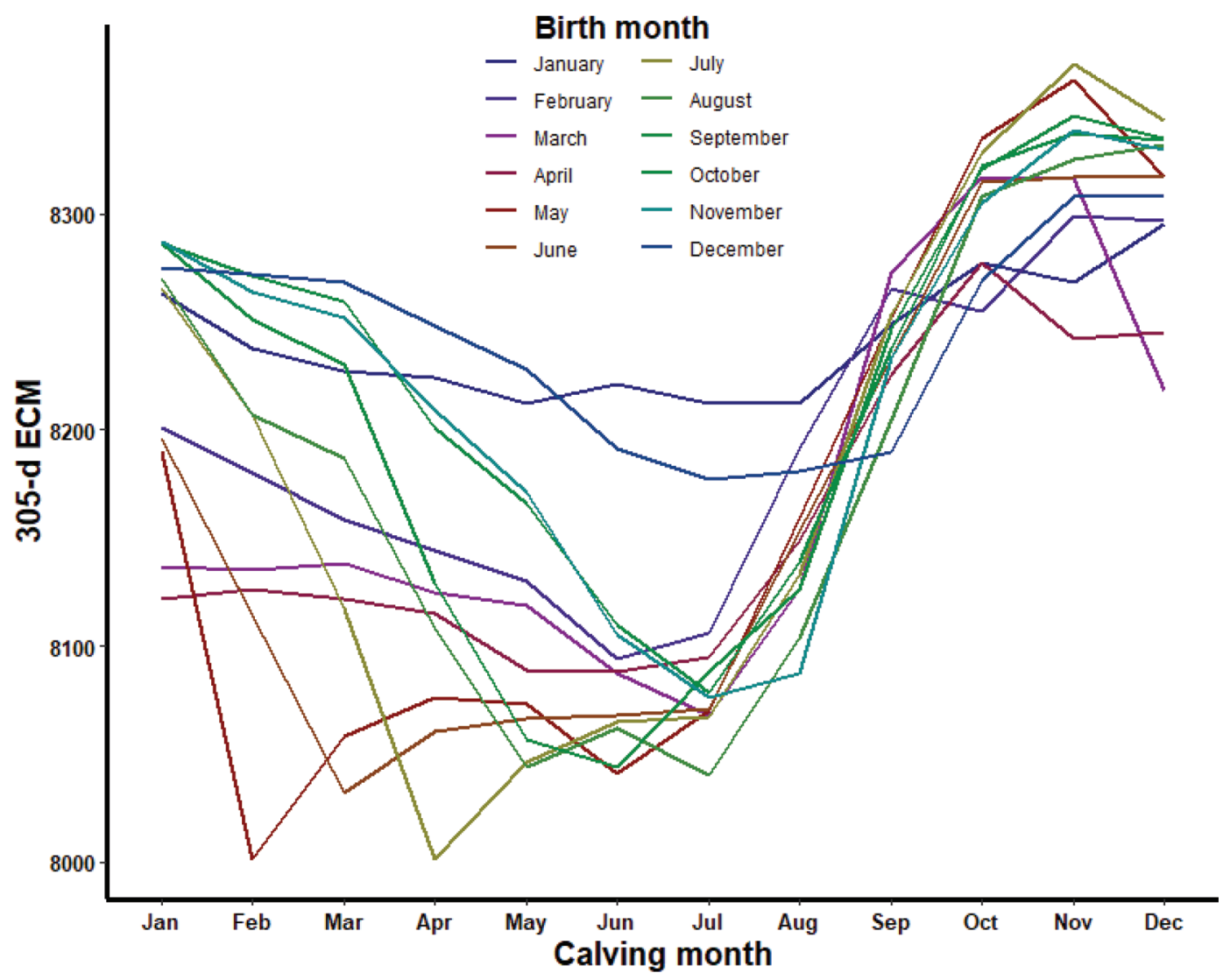

Figure 6. Results of the multivariable regression model including birth month, calving month, age at first calving and parity of the dam; effect of calving month on 305-d ECM, by birth month (LSM \pm SE). 
yield, which we have accounted for in the 305-d ECM, can explain the larger effect of AFC observed in the present study.

Our results indicate that AFC is an important determinant of first-lactation milk yield. On one hand, a lower AFC means that fewer replacement heifers are required and total rearing costs are reduced (Tozer and Heinrichs, 2001). On the other hand, this study shows that in younger heifers, a lower ECM, and thus reduced revenue, is expected during first lactation. However, van Pelt et al. (2016) showed on similar data that calving at a younger age results in higher survival rates. The results of this study also suggest that in heifers with an older AFC, the economic balance might be better than originally thought because of the higher milk yield return. However, a thorough economic analysis would have to be carried out before the current recommendations on optimal calving age could be refuted. After all, besides milk yield, there are other important factors influencing profitability that were not evaluated in this study. Further research on this topic should take into account management factors, rearing costs, yield of milk and solids, and survivability in relation to AFC (Mohd Nor et al., 2013; Sherwin et al., 2016).

\section{Seasonal Patterns}

Figure 1 shows the largest number of heifers calved during autumn, which is in accordance with previous studies conducted in the same area (Froidmont et al., 2013; Van Eetvelde et al., 2017). This could be explained by the fact that, before the abolishment of the milk quota regulation in Europe, milk cooperatives used to pay a higher price for winter milk (Mayne et al., 2011). Hence, farmers were stimulated to concentrate calvings during the autumn months. In the present study, both month of birth and month of calving influenced a heifer's milk yield, with calving month having a 5-times-larger effect.

Birth Month. Overall, a larger 305-d ECM was seen in heifers born during the colder months (October-January) compared with heifers born between March and August $(P<0.05)$. This is in contrast with the results of our and other previous studies, reporting a higher 305-d milk yield during first lactation in summer-born heifers (Soberon et al., 2012; Chester-Jones et al., 2017; Van Eetvelde et al., 2017). Soberon et al. (2012) also reported conflicting results, as in their study, the effect of birth season on milk yield differed between herds. The authors suggested the calves' energy intake above maintenance to be the main reason; in herds where a constant amount of milk is fed throughout the year, energy consumption above maintenance is expected to be higher in summer-born calves, leading to a higher growth rate and followed by a better performance. However, this could not be affirmed by Chester-Jones et al. (2017), who described a higher feed intake, body weight, and growth rate in calves born during colder seasons. As preweaning growth rate has been shown to be an important predictor of first-lactation milk yield (Moallem et al., 2010; Soberon et al., 2012), differences in energy intake, and thus growth, in young calves could explain why seasonal patterns are herd-dependent. Indeed, herd factors such as feeding strategies and vaccination status during early life have been related to first-lactation performance of heifers (Mohd Nor et al., 2013). In addition, other management factors (such as housing and measures to prevent cold or heat stress), might be more important than birth season, but this was beyond the scope of this study.

Calving Month. Apart from birth month, calving month significantly influenced the first-lactation performance. Calving between October and December resulted in the highest 305-d ECM during first lactation, whereas the lowest milk yield was seen in heifers calving in June and July $(P<0.001)$. This seasonal difference in milk yield could not directly be attributed to a younger AFC, as June- and July-born heifers were on average $784 \pm 76 \mathrm{~d}$ old at calving compared with $783 \pm 68 \mathrm{~d}$ in heifers born in October to December $(P$ $<0.001$ ). In addition, the birth month-calving month interactions are difficult to explain and were not related to AFC of the heifers, as for example, Novembercalvers born in April produced $127 \mathrm{~kg}$ less 305d-ECM but were $92 \mathrm{~d}$ older compared with November-calvers born in July. Hence, we suggest other mechanisms to be responsible for the month-of-calving effect on milk yield during first lactation.

Our results are in line with previous studies reporting a lower milk yield in heifers calving in summer (Maciuc, 2009; Mohd Nor et al., 2013), potentially caused by higher environmental temperatures and thus lower feed intake during the critical (early) stage of lactation (Maciuc, 2009). In contrast however, Froidmont et al. (2013) reported a higher milk yield when first calving took place during summer or autumn. The authors stated that this might be due to differences in feeding because animals that calve during summer are grazing during the initial lactation phase and are in production throughout winter, receiving on average higher feed levels compared with winter- or spring-calvers. Thus, in accordance with differences seen in the effect of birth season, the effect of calving season might be largely dependent on herd factors, especially in herds in which grazing is applied. However, as detailed management data were not available for the farms included in this study, it was not possible to account for the effect of feeding strategies on a heifer's performance. 
In addition, differences in photoperiods $(\mathbf{P P})$ should be considered, as longer PP during lactation have been shown to be associated with increased milk yield in cattle (Dahl and Petitclerc, 2003). Short PP during the dry period, followed by longer PP after calving result in the greatest increase in milk yield, whereas long PP during the dry period potentially suppress milk yield in the subsequent lactation (Miller et al., 2000; Auchtung et al., 2005). Even in heifers, shorter PP during the last $60 \mathrm{~d}$ of gestation have been associated with increased first-lactation milk yield (Dahl and Petitclerc, 2003), which is suggested to be caused by a greater responsiveness to prolactin during the transition period (Auchtung et al., 2005). This might partly explain the results found in our study: in heifers calving during the longest days of the year (June-July), PP will shorten during early lactation, potentially suppressing milk yield. However, the effect of PP cannot explain the larger milk yield in autumn-calving dams found in this study. Hence, further research is necessary to explore the underlying mechanisms related to the seasonal pattern in milk yield.

\section{Parity of the Dam}

Parity of the dam only had a limited effect on firstlactation milk yield $\left(\mathrm{R}^{2}=0.002\right)$, with daughters of first- and second-parity dams producing the highest 305-d ECM. As the effect of dam parity is a combination of both a genetic effect and other maternal effects, the higher genetic merit in younger dams might a least partly explain why they give birth to more productive daughters. In the present study, it was not possible to separate the direct genetic effect from other maternal effects. However, according to the findings of FuerstWaltl et al. (2004), even when additive genetic effects are included in the model, a maternal age effect on milk yield of the offspring is seen.

In contrast with previous studies, reporting a better outcome for daughters of first-parity cows compared with second-parity cows (Fuerst-Waltl et al., 2004; González-Recio et al., 2012; Astiz et al., 2014), our present results show no differences in performance between heifers born out of first- and second-parity dams. In our previous study based on a rather limited data set, no maternal effect on milk yield was found (Van Eetvelde et al., 2017), presumably because of the young average age of the dams ( $80 \%$ of dams were younger than $4 \mathrm{yr}$ old). Indeed, González-Recio et al. (2012) found the negative effect of maternal lactation on offspring performance to increase with increasing parity of the dam. Hence, the difference in milk yield between offspring of first- and second-parity dams might be small compared with differences with higher-parity dams. The results of the present study might be considered as an extra argument - in addition to the higher genetic merit - to use sexed female semen on the youngest cows in the herd, as these dams are suggested to produce the most productive daughters.

\section{CONCLUSIONS}

Results of the present study show AFC to be an important determinant of milk yield during first lactation. Furthermore, calving season was found to have a larger effect on first-lactation performance than birth season, with the highest milk yield recorded in heifers calving in autumn. A limited effect of birth month on milk yield was noticed, possibly masked by large herd-to-herd differences in the early postnatal management of calves. Finally, dams with a parity of 3 or more are shown to negatively influence their daughters' milk yield.

\section{ACKNOWLEDGMENTS}

The authors have not stated any conflicts of interest.

\section{REFERENCES}

Astiz, S., A. Gonzalez-Bulnes, F. Sebastian, O. Fargas, I. Cano, and P. Cuesta. 2014. Maternal aging affects life performance of progeny in a Holstein dairy cow model. J. Dev. Orig. Health Dis. 5:374-384. https://doi.org/10.1017/S2040174414000361.

Auchtung, T. L., A. G. Rius, P. E. Kendall, T. B. McFadden, and G. E. Dahl. 2005. Effects of photoperiod during the dry period on prolactin, prolactin receptor, and milk production of dairy cows. J. Dairy Sci. 88:121-127. https://doi.org/10.3168/jds.S0022 $-0302(05) 72669-2$

Azen, R., and D. V. Budescu. 2003. The dominance analysis approach for comparing predictors in multiple regression. Psychol. Methods 8:129-148. https://doi.org/10.1037/1082-989X.8.2.129.

Azen, R., and N. Traxel. 2009. Using dominance analysis to determine predictor importance in logistic regression. J. Educ. Behav. Stat. 34:319-347. https://doi.org/10.3102/1076998609332754.

Bach, A. 2011. Associations between several aspects of heifer development and dairy cow survivability to second lactation. J. Dairy Sci. 94:1052-1057. https://doi.org/10.3168/jds.2010-3633.

Bates, D., M. Mächler, B. Bolker, and S. Walker. 2015. Fitting linear mixed-effects models using lme4. J. Stat. Softw. 67:1-48. https:// doi.org/10.18637/jss.v067.i01.

Bustos, C., and F. C. Soares. 2019. Dominanceanalysis: Dominance Analysis. https://CRAN.R-project.org/package= dominanceanalysis.

Chester-Jones, H., B. J. Heins, D. Ziegler, D. Schimek, S. Schuling, B. Ziegler, M. B. de Ondarza, C. J. Sniffen, and N. Broadwater. 2017. Relationships between early-life growth, intake, and birth season with first-lactation performance of Holstein dairy cows. J. Dairy Sci. 100:3697-3704. https://doi.org/10.3168/jds.2016-12229.

CRV. 2018a. Annual Statistics Flanders. Cooperative CRV, Arnhem, The Netherlands. Accessed Dec. 4, 2019. https://crvbe-be6.kxcdn .com/wp-content/uploads/2019/04/Jaarstatistieken-2018-VLA -totaal-1.pdf.

CRV. 2018b. Annual Statistics the Netherlands. Cooperative CRV, Arnhem, The Netherlands. Accessed Dec. 4, 2019. https:// www.cooperatie-crv.nl/wp-content/uploads/2018/03/Totaal -Jaarstatistieken-2017-NL.pdf. 
Curran, R. D., K. A. Weigel, P. C. Hoffman, J. A. Marshall, C. K. Kuzdas, and W. K. Coblentz. 2013. Relationships between age at first calving; herd management criteria; and lifetime milk, fat, and protein production in Holstein cattle. Appl. Anim. Sci. 29:1-9. https://doi.org/10.15232/S1080-7446(15)30188-1.

Dahl, G. E., and D. Petitclerc. 2003. Management of photoperiod in the dairy herd for improved production and health. J. Anim. Sci. 81(Suppl. 3):11-17. https://doi.org/10.2527/2003.81suppl_311x.

Denis-Robichaud, J., R. L. A. Cerri, A. Jones-Bitton, and S. LeBlanc. 2016. Survey of reproduction management on Canadian dairy farms. J. Dairy Sci. 99:9339-9351. https://doi.org/10.3168/ jds.2016-11445.

Eastham, N. T., A. Coates, P. Cripps, H. Richardson, R. Smith, and G. Oikonomou. 2018. Associations between age at first calving and subsequent lactation performance in UK Holstein and HolsteinFriesian dairy cows. PLoS One 13:e0197764. https://doi.org/10 .1371/journal.pone.0197764.

Ettema, J. F., and J. E. P. Santos. 2004. Impact of age at calving on lactation, reproduction, health, and income in first-parity Holsteins on commercial farms. J. Dairy Sci. 87:2730-2742. https:// doi.org/10.3168/jds.S0022-0302(04)73400-1.

Froidmont, E., P. Mayeres, P. Picron, A. Turlot, V. Planchon, and D. Stilmant. 2013. Association between age at first calving, year, and season of first calving and milk production in Holstein cows. Animal 7:665-672. https://doi.org/10.1017/S1751731112001577.

Fuerst-Waltl, B., A. Reichl, C. Fuerst, R. Baumung, and J. Sölkner. 2004. Effect of maternal age on milk production traits, fertility, and longevity in cattle. J. Dairy Sci. 87:2293-2298. https://doi .org/10.3168/jds.S0022-0302(04)70050-8.

González-Recio, O., M. Pérez-Cabal, and R. Alenda. 2004. Economic value of female fertility and its relationship with profit in Spanish dairy cattle. J. Dairy Sci. 87:3053-3061. https://doi.org/10.3168/ jds.S0022-0302(04)73438-4.

González-Recio, O., E. Ugarte, and A. Bach. 2012. Trans-generational effect of maternal lactation during pregnancy: A Holstein cow model. PLoS One 7:e51816. https://doi.org/10.1371/journal.pone .0051816

Hare, E., H. D. Norman, and J. R. Wright. 2006. Trends in calving ages and calving intervals for dairy cattle breeds in the United States. J. Dairy Sci. 89:365-370. https://doi.org/10.3168/jds .S0022-0302(06)72102-6.

Haworth, G. M., W. P. Tranter, J. N. Chuck, Z. Cheng, and D. C. Wathes. 2008. Relationships between age at first calving and first lactation milk yield, and lifetime productivity and longevity in dairy cows. Vet. Rec. 162:643-647. https://doi.org/10.1136/vr.162 .20 .643 .

IFCN (International Farm Comparison Network). 2012. IFCN Dairy Report 2012: For a Better Understanding of Milk Production World-wide. T. Hemme, ed. IFCN, Kiel, Germany.

Jago, J. G., and D. P. Berry. 2011. Associations between herd size, rate of expansion and production, breeding policy and reproduction in spring-calving dairy herds. Animal 5:1626-1633. https://doi.org/ 10.1017/S1751731111000516.

Jairath, L. K., J. F. Hayes, and R. I. Cue. 1995. Correlations between first lactation and lifetime performance traits of Canadian Holsteins. J. Dairy Sci. 78:438-448. https://doi.org/10.3168/jds.S0022 -0302(95)76653-X.
Maciuc, V. 2009. Influence of the calving season on the milk yield given by a Friesian population, imported from the Netherlands. Lucrări Ştiinţifice Seria Zootehnie 52:340-344.

Mayne, C. S., W. J. McCaughey, and C. P. Ferris. 2011. Dairy farm management systems: Non-seasonal, pasture-based milk production systems in Western Europe. Pages 44-51 in Encyclopedia of Dairy Sciences. 2nd ed. J. W. Fuquay, P. F. Fox, and P. L. H. Sweeny, ed. Academic Press, San Diego, CA.

Miller, A. R. E., R. A. Erdman, L. W. Douglass, and G. E. Dahl. 2000 Effects of photoperiodic manipulation during the dry period of dairy cows. J. Dairy Sci. 83:962-967. https://doi.org/10.3168/jds .S0022-0302(00)74960-5.

Moallem, U., D. Werner, H. Lehrer, M. Zachut, L. Livshitz, S. Yakoby, and A. Shamay. 2010. Long-term effects of ad libitum whole milk prior to weaning and prepubertal protein supplementation on skeletal growth rate and first-lactation milk production. J. Dairy Sci. 93:2639-2650. https://doi.org/10.3168/jds.2009-3007.

Mohd Nor, N., W. Steeneveld, T. van Werven, M. C. M. Mourits, and H. Hogeveen. 2013. First-calving age and first-lactation milk production on Dutch dairy farms. J. Dairy Sci. 96:981-992. https: //doi.org/10.3168/jds.2012-5741.

Nilforooshan, M. A., and M. A. Edriss. 2004. Effect of age at first calving on some productive and longevity traits in Iranian Holsteins of the Isfahan Province. J. Dairy Sci. 87:2130-2135. https://doi.org/ 10.3168/jds.S0022-0302(04)70032-6.

Pirlo, G., F. Miglior, and M. Speroni. 2000. Effect of age at first calving on production traits and on difference between milk yield returns and rearing costs in Italian Holsteins. J. Dairy Sci. 83:603608. https://doi.org/10.3168/jds.S0022-0302(00)74919-8.

R Core Team. (2019). R: A language and environment for statistical computing. R foundation for Statistical Computing. Vienna, Austria. http://www.R-project.org/.

Sherwin, V. E., C. D. Hudson, A. Henderson, and M. J. Green. 2016. The association between age at first calving and survival of first lactation heifers within dairy herds. Animal 10:1877-1882. https:/ /doi.org/10.1017/S1751731116000689.

Soberon, F., E. Raffrenato, R. W. Everett, and M. E. Van Amburgh. 2012. Preweaning milk replacer intake and effects on long-term productivity of dairy calves. J. Dairy Sci. 95:783-793. https://doi .org/10.3168/jds.2011-4391.

Tozer, P. R., and A. J. Heinrichs. 2001. What affects the costs of raising replacement dairy heifers: a multiple-component analysis. J. Dairy Sci. 84:1836-1844. https://doi.org/10.3168/jds.S0022 $-0302(01) 74623-1$

USDA. 2002. Dairy 2002. Part I: Reference of dairy health and management in the United States, 2002. Rep. N377.1202. National Animal Health Monitoring System. Animal and Plant Health Inspection Service. USDA, Fort Collins, CO.

Van Eetvelde, M., M. M. Kamal, L. Vandaele, and G. Opsomer. 2017. Season of birth is associated with first-lactation milk yield in Holstein Friesian cattle. Animal 11:2252-2259. https://doi.org/10 $.1017 /$ S1751731117001021.

van Pelt, M. L., G. de Jong, and R. F. Veerkamp. 2016. Changes in the genetic level and the effects of age at first calving and milk production on survival during the first lactation over the last 25 years. Animal 10:2043-2050. https://doi.org/10.1017/ S1751731116001282. 